\title{
PENINGKATAN HASIL BELAJAR K3LH MELALUI PEMBERIAN KUIS PEMBELAJARAN PADA SISWA KELAS X SMK NEGERI 1 MARE KABUPATEN BONE
}

\author{
Improved The Result of The K3LH Learning Trhought Giving The Learning Quiz to \\ The Students at X Grade In SMK Negeri 1 Mare of Bone District
}

\author{
Riska Rahmayana1), Kadirman²), dan Purnamawati3). \\ Program Studi Pendidikan Teknologi Pertanian \\ Fakultas Teknik \\ Universitas Negeri Makassar \\ riska.ptp@gmail.com
}

\begin{abstract}
ABSTRAK
Penelitian ini merupakan penelitian tindakan kelas (Classroom Action Research) yang bertujuan untuk meningkatkan hasil belajar siswa. Tujuan dari penelitian ini adalah; (1) untuk mengetahui aktivitas yang ada dalam pembelajaran K3LH melalui pemberian kuis (2) untuk mengetahui hasil belajar K3LH setelah menerapkan metode pemberian kuis (3) untuk mengetahui pengaruh pemberian kuis terhadap hasil belajar K3LH. Subjek penelitian ini terdiri dari 34 siswa. Teknik pengumpulan data yang digunakan adalah observasi dan pemberian tes setiap akhir siklus sesuai dengan materi yang diajarka. Prosedur penelitian meliputi tahap: (a) perencanaan, (b) pelaksanaan, (c) observasi, dan (d) refleksi. Data yang terkumpul dianalisis dengan menggunakan analisis data deskriptif kualitatif. Berdasarkan hasil penelitian, dapat disimpulkan bahwa melalui pemberian kuis dapat meningkatkan hasil belajar siswa. yaitu $50 \%$ meningkat menjadi $82,36 \%$ dengan Kriteria Ketuntasan Minimum (KKM) yaitu 70.

Kata Kunci : Peningkatan, Kuis, Hasil Belajar
\end{abstract}

\section{ABSTRACT}

This reseacrh is a classroom action research which aims to improve the learning outcomes of students. The aims of this research is; (1) to know the activity in learning of $\mathrm{K} 3 \mathrm{LH}$ throught giving the quiz (2) to know the results of K3LH learning after applied the method of giving the quiz (3) to know the influence of giving the quiz to the results of K3LH learning. The subject of this reseach consists of 34 students. The techniques of collection data using observation and giving test at the end of the cycle that related to materials on teaching. Research procedures consist of: (a) planning, (b) implementation, (c)observation and (d) reflection. The data collected will be analyzed by qualitative descriptive data analysis. Based on the results of the research, it can be conclud that through giving the quiz can improve the result of students learning. That is $50 \%$ increase to $82,36 \%$ with Minimum Completeness Criterion (KKM) that is 70.

Key Words: Improved, Quiz, The Results Of The Study 


\section{PENDAHULUAN}

Pendidikan merupakan faktor utama yang menentukan kualitas suatu bangsa. Pendidikan bukanlah sesuatu yang bersifat statis melainkan sesuatu yang bersifat dinamis sehingga selalu menuntut adanya suatu perbaikan yang bersifat terus menerus.

Pendidikan pada hakikatnya adalah usaha mencerdaskan dan membudayakan manusia. Hal ini karena manusia merupakan pribadi yang utuh dan kompleks. Hakikat manusia berkembang mengikuti perkembangan zaman, maka dari itu ilmu pengetahuan juga harus ikut dikembangkan sesuai dengan perkembangan zaman.

Pesatnya perkembangan ilmu pengetahuan dan teknologi menuntut dukungan dari berbagai faktor, salah satunya adalah faktor pendidikan yang berkualitas dan bermutu. Akan tetapi, sampai saat ini mutu pendidikan masih tetap jadi suatu masalah yang paling menonjol disetiap pembaharuan sistem pendidikan nasional. Salah satu komponen yang berkenaan dengan masalah kualitas pendidikan adalah proses belajar. Hal ini tidak sejalan yang terjadi di lapangan dimana dalam setiap proses belajar mengajar terjadi pembelajaran secara monoton yang menyebabkan murid mengalami depresi mental seperti kebosanan, kurangnya motivasi .

Dilihat dari fakta yang terjadi dikalangan siswa ketika diberikan tugas, berbagai macam sikap yang ditunjukkan siswa terhadap tugas yang diberikan kepadanya tersebut. Sikap tersebut diantaranya yaitu terdapat siswa yang dengan tekun mengerjakan tugas dirumah di hari sebelum tugas itu akan dikumpulkan, ada juga yang mengerjakan tugas sebelum guru masuk ke kelas dan ada juga siswa yang hanya sekedar menyalin pekerjaan siswa lainnya, dan yang paling parah adalah terdapat siswa yang acuh terhadap tugas tersebut dan memilih untuk tidak mengerjakannya.

Kondisi seperti inilah kemudian menjadi salah satu penyebab siswa kesulitan menyerap pelajaran, karena mereka masuk ke kelas tanpa memiliki pengetahuan tentang materi yang telah diajarkan sebelumnya. Siswa yang tidak mampu lagi untuk memahami materi selanjutnya. Oleh karena itu, sehingga kiranya perlu ada tindakan dari pendidik yaitu bagaimana siswa mempelajari ulang materi yang sudah diajarkan dan mencermati materi yang akan dipelajari berikutnya. Sehingga, hal ini kemudian akan memberikan dampak negatif terhadapi hasil belajar siswa, atau dengan kata lain hal ini menyebabkan hasil belajar siswa menjadi rendah.

Peningkatan hasil belajar siswa yang harus dilakukan adalah upaya seorang tenaga pendidik mencari pendekatan, metode, model serta strategi pembelajaran yang cocok dengan kondisi siswanya. pendekatan, metode, model serta strategi yang harus dipilih oleh tenaga pendidik sebisa mungkin melibatkan siswa, agar mereka mampu bereksplorasi untuk membentuk kompetensi, dengan menggali berbagai potensi yang ada pada diri siswa. Tugas tenaga pendidik di kelas, tidak hanya menyampaikan informasi kepada peserta didik, tetapi harus menjadi fasilitator yang bertugas memberikan suatu pembahasan kepada siswa yang dimana pembahasan tersebut bisa menciptakan pendiskusian antara siswa dan pendidik. Agar pembahasan tersebut bisa betulbetul dipahami bukan hanya diketahui.

Salah satu tindakan yang dapat dipilih adalah dengan pemberian kuis, 
kuis merupakan penilaian singkat yang digunakan dalam pendidikan dan bidang serupa mengukur peningkatan pengingatan, pengetahuan, kemampuan, dan keterampilan. Oleh karena itu memberikan kuis merupakan suatu sarana memotivasi belajar siswa. Dengan adanya kuis guru dapat mengetahui keputusan apa yang diambil tentang berhasil atau tidaknya pencapaian tujuan pembelajaran yang telah ditetapkan, sedangkan bagi siswa dapat mengukur kemampuannya sendiri. Menurut Hamzah (Nurlsmi:2007) "pemberian kuis setiap awal pembelajaran dimaksudkan untuk melihat keseriusan murid dalam belajar dan menilai kesiapan belajar siswa, artinya penilaian sejauh mana siswa telah memiliki kemapuan-kemampuan atau keterampilan yang diperlukan (prasyarat) untuk mempelajari suatu bahan pelajaran. Selain itu pemberian kuis bertujuan untuk meningkatkan motivasi siswa agar lebih bergairah dan menekuni materi pelajaran selama berlangsungnya proses belajar mengajar".

Selanjutnya Majid (2012:56) mengemukakan bahwa "kuis adalah isian singkat dan menanyakan hal-hal yang prinsip. Biasanya dilakukan sebelum pelajaran dimulai kurang lebih 5-10 menit. Kuis mempunyai fungsi ganda yaitu untuk mengukur kemampuan siswa dan untuk mengukur keberhasilan program pembelajaran". Keuntungan proses belajar mengajar yang dilakukan dengan penerapan pemberian kuis disetiap awal pembelajaran adalah dapat mendorong inisiatif siswa, meningkatkan minat dan dapat meningkatkan hasil belajarnya. Pengajaran yang menerapkan pemberian kuis akan menuntun siswa untuk terus belajar guna untuk membangkitkan semangat belajar siswa. Menurut Hermawan (2012), kelebihan proses belajar mengajar yang dilakukan dengan penerapan pemberian kuis adalah: 1) dapat mendorong inisiatif siswa bertanggung jawab, kreatif, tekun, giat, rajin belajar, dan berdiri sendiri, 2) pengetahuan yang diperoleh siswa dari hasil belajar akan dapat diingat lebih lama, 3) meningkatkan minat dan dapat meningkatkan hasil belajarnya.

SMK Negeri 1 Mare merupakan salah satu sekolah yang letaknya sangat strategis di kabupaten Bone sehingga memiliki banyak siswa yang ingin bergabung. Salah satu mata pelajaran di kompetensi kejuruan penyuluhan pertanian adalah Kesehatan Keselamatan Kerja dan Lingkungan Hidup (K3LH). Menurut Suryani (2011) $\mathrm{K} 3 \mathrm{LH}$ adalah suatu upaya perlindungan agar karyawan/tenaga kerja selalu dalam keadaan selamat dan sehat selama melakukan pekerjaannya di tempat kerja termasuk juga orang lain yang memasuki tempat kerja maupun proses produk dapat secara aman dalam produksinya.

Definisi K3LH yang lainnya adalah suatu upaya perlindungan agar karyawan/tenaga kerja selalu dalam keadaan selamat dan sehat selama melakukan pekerjaannya di tempat kerja termasuk juga orang lain yang memasuki tempat kerja maupun proses produk dapat secara aman dalam produksinya, yang berkembang seiring perkembangan ilmu pengetahuan dan teknologi (IPTEK).

Berdasarkan hasil observasi awal di SMK Negeri 1 Mare kelas $X$ pada mata pelajaran K3LH (Kesehatan Keselamatan Kerja dan Lingkungan Hidup) masih tergolong sangat rendah. $\mathrm{Hal}$ ini dapat dilihat dari hasil belajar siswa berupa daftar nilai guru kelas $X$ ditemukan rata-rata nilai ujian tengah 
semester K3LH dengan jumlah keseluruhan 34 peserta didik, ada 10 peserta didik diantaranya telah memenuhi Kriteria Ketuntasan Minimal (KKM) yang telah dipersyaratkan yaitu 70, sedangkan 24 peserta didik lainnya belum memenuhi Kriteria Ketuntasan Minimal (KKM)) yang telah dipersyaratkan yaitu 70 .

Guru mata pelajaran K3LH di sekolah ini sudah melakukan proses pembelajaran secara maksimal namun hasil akhir yang diperoleh siswa hanya seperti itu masih ada yang belum mencapai nilai KKM. Hal ini yang terjadi dalam proses pembelajaran K3LH di SMK Negeri 1 Mare perlu dicarikan solusi, karena berdampak negatif bagi prestasi belajar siswa jika terus menerus dibiarkan seperti ini.

Berdasarkan paparan di atas, maka peneliti tertarik untuk melakukan perbaikan terhadap proses belajar mengajar K3LH pada siswa kelas X SMK Negeri 1 Mare Kecamatan Mare Kabupaten Bone melalui sebuah Penelitian Tindakan Kelas (PTK) dengan judul "Peningkatkan Hasil belajar K3LH Melalui Pemberian Kuis Pada Siswa Kelas X SMK Negeri 1 Mare Kab.Bone".

\section{Tujuan Penelitian}

Tujuan yang ingin dicapai dalam penelitian ini adalah : untuk mengetahui aktivitas, hasil belajar, dan pengaruh pemberian kuis siswa kelas X.PP SMK Negeri 1 Mare melalui pemberian kuis pada mata pelajaran K3LH.

\section{METODOLOGI PENELITIAN}

Penelitian ini adalah penelitian tindakan kelas (classroom action research), Penelitian ini dimaksudkan untuk memberikan informasi bagaimana cara untuk meningkatkan hasil belajar siswa dengan menggunakan metode Pemberian kuis.

Desain dalam penelitian tindakan kelas ini peneliti menggunakan model Kemmis dan Mc. Taggart. Pelaksanaan penelitian tindakan meliputi empat langkah yaitu perencanaan (planning), pelaksanaan tindakan (action), pengamatan (observation), dan refleksi (reflection). Setiap langkah pelaksanaan termuat dalam suatu siklus. Siklus dihentikan jika penelitian yang dilakukan sesuai dengan rencana dan mengalami peningkatan.

Penelitian ini dilaksanakan di SMK Negeri 1 Mare dengan subjek penelitian adalah siswa kelas X.PP SMK Negeri 1 Mare berjumlah 34 siswa. Waktu penelitian dilaksanakan semester genap tahun ajaran 2015/2016.

Penelitian tindakan kelas ini dilaksanakan dalam dua siklus kegiatan yaitu siklus I (pertama) dilaksanakan selama 4 kali pertemuan, dan siklus ॥ hanya dilaksanakan 3 kali pertemuan.

Pengolahan data pada penelitian ini dianalisis secara kuantitatif dan kualitatif. Menurut Tohirin (2012:3) "penelitian kualitatif merupakan suatu penelitian yang bermaksud memahami fenomena tentang apa yang dialami oleh subjek penelitian misalnya perilaku, persepsi, motivasi, tindakan dan lain-lain secara holistik dan dengan cara deskripsi dalam bentuk kata-kata dan bahasa pada suatu konteks khusus yang alami serta dengan memanfaatkan berbagai metode alamiah".

Untuk analisis secara kuantitatif digunakan analisis deskriptif, yaitu nilai rata-rata dan persentase. Selain itu, tabel frekuensi nilai minimum dan maksimum yang siswa peroleh pada pokok bahasan yang diajarkan. Dalam 
hal analisis kualitatif dilakukan dengan melihat hasil observasi selama proses belajar mengajar dari tiap siklus.

\section{HASIL DAN PEMBAHASAN}

Hasil dan analisis data penelitian ini dibuat berdasarkan data yang diperoleh dari kegiatan penelitian tentang hasil belajar siswa pada mata pelajaran $\mathrm{K} 3 \mathrm{LH}$ melalui pemberian kuis yang dilaksanakan di SMK Negeri 1 Mare. Pelaksanaan penelitian ini dilakukan selama 2 siklus. Adapun yang dianalisis adalah hasil tes awal, tes akhir siklus I dan siklus II. Hasil dan pembahasan yang diperoleh dari dua siklus selama penelitian ini adalah sebagai berikut:

\section{Hasil Penelitian}

\section{Tes Awal}

Pada tabel 4.1 menunjukkan bahwa skor rata-rata belajar siswa pada mata pelajaran K3LH setelah tes awal adalah $59,50 \%$ dari skor ideal, yaitu 100. Skor maksimum yang diperoleh siswa adalah 80 , skor minimum 45 dan rentang skor adalah 35. Apabila kemampuan siswa dalam menyelesaikan soal-soal pada tes awal dianalisis, maka persentase ketuntasan belajar siswa tes awal persentase ketuntasan belajar siswa sebesar $26,47 \%$ yaitu 9 dari 34 siswa termasuk dalam kategori tuntas, sedangkan $73,53 \%$ atau 25 dari 34 siswa termasuk dalam kategori tidak tuntas.

Hal ini menunjukkan bahwa dari 34 jumlah siswa masih ada 25 siswa yang belum tuntas hasil belajarnya dan memerlukan perbaikan pada pembelajaran siklus I.

\section{Siklus I}

Setelah dilakukan pembelajaran K3LH dengan menggunakan metode pemberian Kuis diperoleh hasil belajar siswa yang disajikan pada gambar dibawah ini:

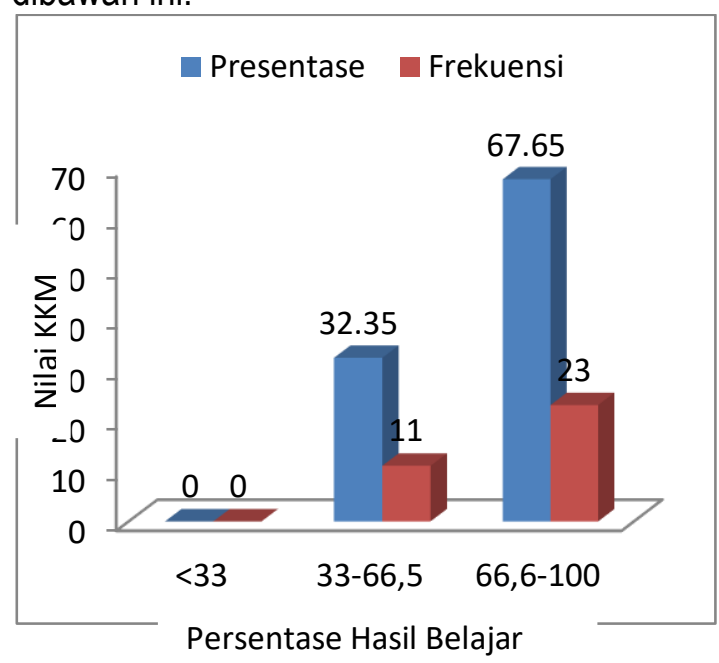

\section{Gambar 1. Data Distribusi Frekuensi Nilai Tes Siklus I}

Dari gambar 1 diperoleh bahwa dari 34 siswa kelas X SMK Negeri 1 Mare terdapat 11 orang atau $32,35 \%$ dengan kategori cukup, 23 orang atau $67,65 \%$ dengan kategori baik. Untuk persentase ketuntasan belajar siswa pada tes siklus I diperoleh bahwa dari 34 siswa kelas $X$ SMK Negeri 1 Mare terdapat 17 orang atau $50 \%$ yang mencapai ketuntasan, dan masih terdapat 17 siswa atau 50\% yang belum mencapai batas ketuntasan atau belum kompeten berdasarkan kriteria ketuntasan minimal (KKM) dalam kurikulum satuan tingkat pendidikan (KTSP) serta tuntutan sekolah yakni minimal $80 \%$, maka dengan demikian perlu dilakukannya penelitian berlanjut pada siklus berikutnya. 


\section{Hasil Tes Siklus II}

Setelah dilakukan perbaikan sesuai hasil refleksi pada siklus I, diperoleh hasil belajar siswa pada mata pelajaran $\mathrm{K} 3 \mathrm{LH}$ dengan menggunakan metode pemberian kuis seperti yang tertera pada gambar di bawah ini:

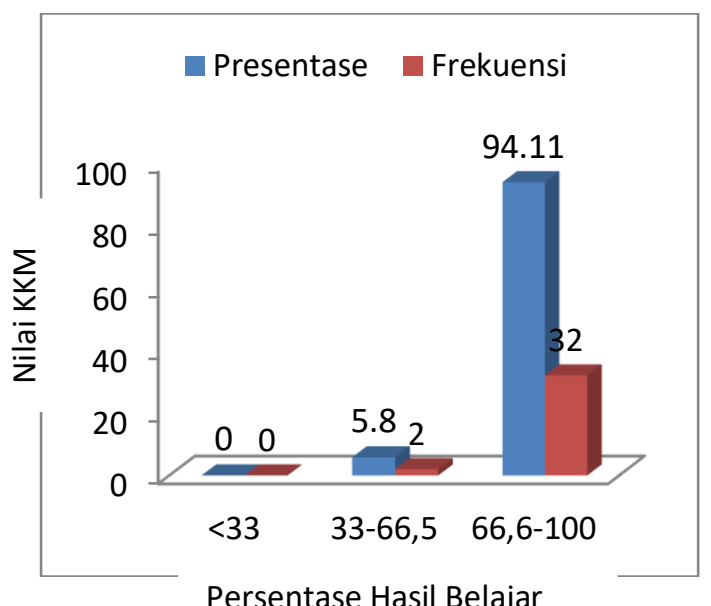

Gambar 2. Data Distribusi Frekuensi Nilai Tes Siklus II

Dari hasil gambar 2 diperoleh bahwa dari 34 siswa kelas X SMK Negeri 1 Mare terdapat 2 orang atau 5,8\% dengan kategori cukup, 32 orang atau $94,11 \%$. Untuk persentase ketuntasan belajar siswa tes siklus II diperoleh bahwa dari 34 siswa kelas X SMK Negeri 1 Mare sudah $82,36 \%$ yang telah mencapai ketuntasan.

Dari daftar frekuensi dapat disimpulkan bahwa secara klasikal (80) siswa sudah bisa dikatakan berkompeten, karena sebanyak 28 Siswa atau $82,36 \%$ yang memperoleh hasil nilai pada siklus $\| \geq 70$ atau diatas penetapan kriteria ketuntasan minimal yang terdapat dalam kurikulum Tingkat Satuan Pendidikan (KTSP) pada lembaga SMK Negeri 1 Mare.

\section{PEMBAHASAN}

Dari hasil observasi yang dilakukan selama dua siklus dengan menerapkan metode pembelajaran pemberian kuis memberikan banyak perubahan pada siswa, diantaranya:

5. Siswa lebih termotivasi untuk giat belajar.

6. Melalui pemberian kuis pembelajaran dapat meningkatkan hasil belajar siswa

7. Siswa tidak tertekan pada saat proses pembelajaran dengan model pembelajaran pemberian kuis

8. Melalui pemberian kuis siswa dapat mengingat lebih lama, aktif dan berfikir kreatif.

9. Siswa merasa senang dengan metode yang diterapkan

10. Perhatian siswa pada saat proses pembelajaran meningkat.

Hasil belajar siswa bisa dikatakan meningkat, dimana tingkat penguasaan yang mereka capai dalam mengikuti proses belajar mengajar dengan menggunakan metode pemberian kuis memiliki hasil yang cukup baik.

Hal ini sesuai dengan keuntungan proses belajar mengajar menggunakan kuis yang dijelaskan oleh Slameto (1991: 56), yaitu dapat mendorong inisiatif siswa, meningkatkan minat dan dapat meningkatkan hasil belajarnya.

Hasil belajar siswa meningkat setelah melalui pengalaman belajar dalam kurun waktu tertentu yang diukur dengan menggunakan beberapa tes dimana pengalaman belajar yang dilalui berupa beberapa siklus dan beberapa tes yang diberikan oleh guru. 


\section{SIMPULAN DAN SARAN}

\section{Kesimpulan}

Berdasarkan hasil analisis data dan pembahasan, maka dapat disimpulkan bahwa penerapan model pembelajaran pemberian kuis dapat meningkatkan pretasi belajar siswa pada mata pelajaran K3LH di kelas X.PP di SMK Negeri 1 Mare, hal ini dapat dilihat dari ketuntasan secara klasikal pada tes awal yaitu $26,47 \%$, pada siklus I terjadi peningkatan sehingga ketuntasan secara klasikal menjadi $50 \%$ dan pada siklus II terjadi peningkatan hasil belajar sehingga ketuntasan secara klasikal menjadi $82,36 \%$.

\section{Saran}

1. Untuk meningkatkan hasil belajar pada mata pelajaran K3LH perlu menerapkan model pembelajaran pemberian kuis, dengan cara pembawaan yang menarik dan dapat memotivasi siswa untuk mengikuti pelajaran.

2. Kepada guru khususnya guru SMK Negeri 1 Mare dapat mempertimbangkan metode pemberian kuis pembelajaran sebagai upaya untuk meningkatkan hasil belajar siswa.

3. Siswa yang hasil belajarnya tergolong rendah hendaknya diberikan perlakuan khusus berupa bimbingan atau motivasi khusus, memberi kesempatan kepada siswa untuk menyelesaikan masalah sesuai dengan strategi yang dia ketahui.

\section{DAFTAR PUSTAKA}

Hermawan. 2012. Penggunaan
Pemberian Kuis Sebelum
Kegiatan Pembelajaran Sebagai
Upaya Meningkatkan Hasil
Belajar Siswa Kelas VI SDN
Ngabean Kecamatan Secan
Kabupaten Magelang.pdf
http://repository.uksw.edu/handle
/123456789/923 (diakses 11
Februari 2016).
Abdul.2012. Perencanaan
Majid,
Pembelajaran. Bandung: PT
Remaja

Nurismi, 2007. Peningkatan Hasil Belajar Sains Murid Kelas VIIIA SMP Negeri 2 Makassar Melalui Pemberian Kuis Berlapis Disertai Catatan. PTK: FMIPA UNM.

Suryani dkk. 2011. Menerapkan K3LH. Bekasi: Galaxy Puspa Mega

Slameto. 2003. Belajar dan Faktor Faktor yang Mempengaruhi. Jakarta: Rineka Cipta.

Tohirin. 2012. Metode Penelitian Kualitatif Dalam Pendidikan dan Bimbingan Konseling. Jakarta: PT. RajaGrafindo Persada. 